\title{
Landscape Evolution of Antarctica
}

\author{
S. S. R. Jamieson and D. E. Sugden ${ }^{1}$
}

\begin{abstract}
The relative roles of fluvial versus glacial processes in shaping the landscape of Antarctica have been debated since the expeditions of Robert Scott and Ernest Shackleton in the early years of the 20th century. Here we build a synthesis of Antarctic landscape evolution based on the geomorphology of passive continental margins and former northern mid-latitude Pleistocene ice sheets. What makes Antarctica so interesting is that the terrestrial landscape retains elements of a record of change that extends back to the Oligocene. Thus there is the potential to link conditions on land with those in the oceans and atmosphere as the world switched from a greenhouse to a glacial world and the Antarctic ice sheet evolved to its present state. In common with other continental fragments of Gondwana there is a fluvial signature to the landscape in the form of the coastal erosion surfaces and escarpments, incised river valleys, and a continent-wide network of river basins. A selective superimposed glacial signature reflects the presence or absence of ice at the pressure melting point. Earliest continental-scale ice sheets formed around $34 \mathrm{Ma}$, growing from local ice caps centered on mountain massifs, and featured phases of ice-sheet expansion and contraction. These ice masses were most likely cold-based over uplands and warm-based across lowlands and near their margins. For 20 million years ice sheets fluctuated on Croll-Milankovitch frequencies. At $\sim 14 \mathrm{Ma}$ the ice sheet expanded to its maximum and deepened a preexisting radial array of troughs selectively through the coastal mountains and eroded the continental
\end{abstract}

${ }^{1}$ School of GeoSciences, University of Edinburgh, Edinburgh, EH8 9XP, Scotland, UK (Stewart.Jamieson@ed.ac.uk, David.Sugden@ed.ac.uk). shelf before retreating to its present dimensions at $13.5 \mathrm{Ma}$. Subsequent changes in ice extent have been forced mainly by sea-level change. Weathering rates of exposed bedrock have been remarkably slow at high elevations around the margin of East Antarctica under the hyperarid polar climate of the last $\sim 13.5 \mathrm{Ma}$, offering potential for a long quantitative record of ice-sheet evolution with techniques such as cosmogenic isotope analysis.

\section{INTRODUCTION}

Our aim is to synthesize ideas about the evolution of the terrestrial landscapes of Antarctica. There are advantages to such a study. First, the landscape evidence appears to extend back beyond earliest Oligocene times when the first ice sheets formed. Thus events on land may potentially be linked with atmospheric and oceanic change as the world switched from a greenhouse to a glacial world and saw the development of the Antarctic ice sheet. This helps in establishing correlations or leads and lags between different components of the Earth system as a way of establishing cause and effect in global environmental change. Second, the evidence of landscape evolution can be used to refine models of Earth surface processes and their interaction with the wider global system (e.g., by linking conditions in the terrestrial source areas with the marine record of deposition). Third, there are analogies in the Northern Hemisphere of similar-size former Pleistocene ice sheets where the bed is exposed for study. The glaciological body of evidence and theory built on such a base over 150 years is helpful in assessing the nature of the inaccessible topography beneath the Antarctic ice sheet. As such it can illuminate interpretations of subglacial conditions and the dynamics of the present ice sheet.

The crux of any reconstruction of landscape evolution 
in a glaciated area is the extent to which ice sheets have transformed a preexisting fluvial topography. For 150 years there has been debate between those highlighting the erosive power of ice and those indicating its preservative capacity. In 1848 Charles Lyell, on his way over the formerly glaciated eastern Grampians of Scotland to receive a knighthood from Queen Victoria, wrote in his diary, "Here as on Mt Washington and in the White Mountains the decomposing granite boulders and the bare surfaces of disintegrating granite are not scored with glacial furrows or polished." Such observations subsequently led to the idea of unglaciated enclaves that escaped glaciation completely (e.g., in Britain: Linton, 1949; and in North America: Ives, 1966). In Antarctica, scientists on the early 20th-century expeditions of Scott and Shackleton debated the issue, with Taylor (1922) arguing that the landscape was essentially glacial in origin but cut under earlier warmer glacial conditions, and Priestley (1909) arguing that glaciers had modified an existing fluvial landscape. The debate has continued; some argue for dissection of the Transantarctic Mountains by glaciers since the Pliocene (van der Wateren et al., 1999) while others point to the important role of fluvial erosion at an earlier time (Sugden and Denton, 2004).

This paper contributes to this debate by outlining the main variables influencing landscape evolution in Antarctica and then developing hypotheses about what might be expected from both a fluvial and a glacial perspective and the interaction of the two.

\section{WIDER CONTEXT}

East Antarctica consists of a central fragment of Gondwana and is surrounded by rifted margins (Figure 1). The initial breakup of Gondwana around most of East Antarctica took place between $160 \mathrm{Ma}$ and $118 \mathrm{Ma}$. The separation of India and Antarctica took place first, while the separation of Australia from Antarctica took place in earnest after $55 \mathrm{Ma}$. Tasmania and New Zealand separated from the Ross Sea margins at around $70 \mathrm{Ma}$. West Antarctica comprises four separate mini-continental blocks: Antarctic Peninsula, Thurston, Marie Byrd Land, and Ellsworth-Whitmore, thought to be associated with extensional rifting. The drift of the continents opened up seaways around Antarctica and changed ocean circulation and productivity. A long-held view is that this permitted the development of the Antarctic Circumpolar Current, which introduced conditions favorable for glaciation (i.e., cooler temperatures and increased precipitation) (Kennett, 1977). In addition, recent climate modeling studies have suggested that a reduction in atmospheric greenhouse gases may have played an important role in the triggering of Antarctic glaciation (DeConto and Pollard, 2003; Huber and Nof, 2006). Critical dates for the development of ocean gateways are $\sim 33 \mathrm{Ma}$, when a significant seaway opened up between Antarctica and Australia (Stickley et al., 2004), and 31 Ma, when Drake Strait between the Antarctic Peninsula and South America became a significant seaway (Lawver and Gahagan, 2003).

The stepwise glacial history of Antarctica has been pieced together from marine records. Ice sheets first built up at $\sim 34 \mathrm{Ma}$ and their growth was marked by a sudden rise in benthic $\delta^{18} \mathrm{O}$ values (Zachos et al., 1992). On land on the Ross Sea margin of Antarctica, beech forest similar to that in Patagonia today gave way to scrub forest and this change was accompanied by a progressive shift in clay minerals from smectite, typical of forest soils, to chlorite and illite characteristic of polar environments (Raine and Askin, 2001; Ehrmann et al., 2005; Barrett, 2007). Glaciation for the next $\sim 20$ million years was marked by ice volume fluctuations similar in scale to those of the Pleistocene ice sheets of the Northern Hemisphere. These fluctuations are demonstrated
FIGURE 1 The location of Antarctica within Gondwana. The reconstruction shows the fragmentation of the supercontinent at $120 \mathrm{Ma}$ (modified from Lawver et al., 1992).

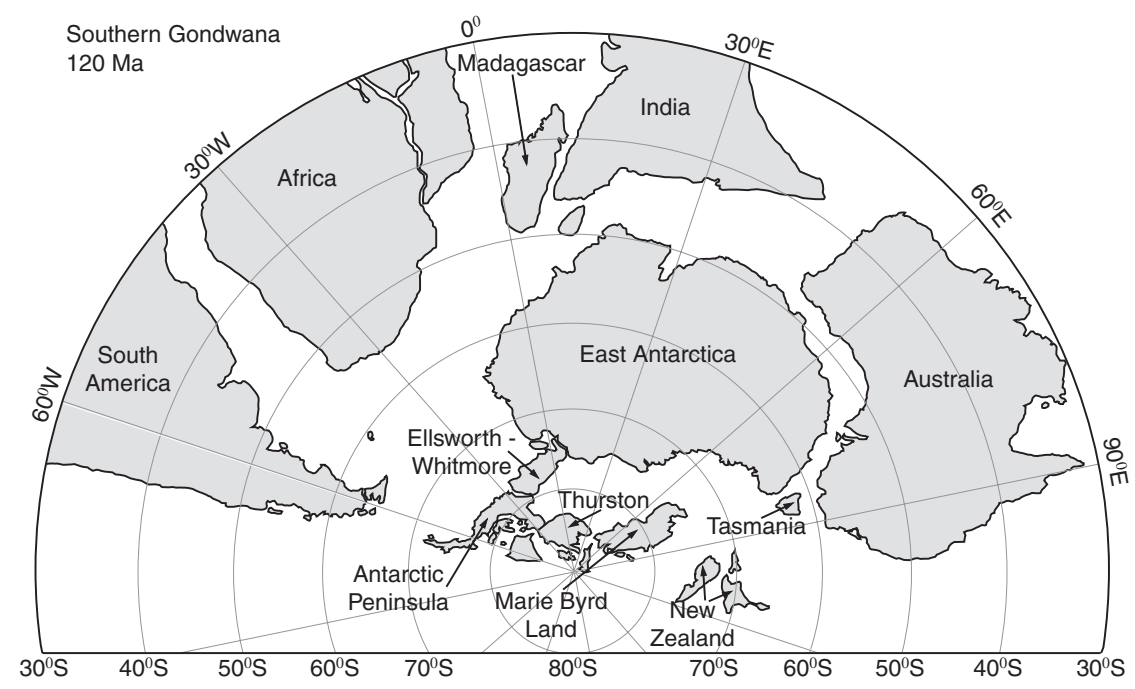


by strata from $34 \mathrm{Ma}$ to $17 \mathrm{Ma}$ cored off the Victoria Land coast near Cape Roberts (Naish et al., 2001; Dunbar et al., forthcoming), high-resolution isotopic records from near Antarctica (Pekar and DeConto, 2006), and by ice-sheet modeling forced by reduced atmospheric $\mathrm{CO}_{2}$ levels and contemporary orbital insolation changes (DeConto and Pollard, 2003). During the same period, the Cape Roberts record shows a progressive decline in meltwater sediments accumulating offshore and a vegetation decline to moss tundra, both indicating progressive cooling. A second stepwise cooling of Pacific surface waters of $6-7^{\circ} \mathrm{C}$ accompanied by a glacial expansion occurred in the mid-Miocene at $\sim 14 \mathrm{Ma}$ and is indicated in the marine isotope record (Shevenell et al., 2004; Holbourn et al., 2005). This event is also recorded in the transition from ash-bearing temperate proglacial deposits to diamict from cold ice in the Olympus Range of South Victoria Land at the edge of the South Polar Plateau (Lewis et al., 2007). Geomorphic evidence indicates that the present hyperarid polar climate of interior Antarctica was established at this time, along with the present structure of polar ocean circulation. Subsequent increases in ice-sheet volume, such as occurred in the Quaternary, involved ice thickening at the coast in response to a lowering of global sea level (Denton et al., 1989).

\section{LANDSCAPE EVOLUTION: THE FLUVIAL SIGNAL}

\section{Hypothesis}

One can predict in qualitative terms the landscape that would accompany the separation of a long-lived continent such as Gondwana. There would be integrated continental-scale river networks similar in scale to that of the Orange River in South Africa and the Murray River in Australia. Presumably these Antarctic rivers would have developed in a semiarid, seasonally wet climate, especially those in the interior of the supercontinent far from the sea. The rifted margins would have been subjected to fluvial processes related to the evolution of passive continental margins. This has been the focus of much research in recent years and is well summarized by Summerfield (2000). Beaumont et al. (2000) developed a coupled surface process-tectonic model of passive continental margin evolution at a classic diverging rift margin (Figure 2A). The main feature is the uplift of the rifted margin inland of a bounding fault running parallel to the coast. The uplift is a result of thermal buoyancy and crustal flexure in response to denudation near the coast and deposition offshore. Erosion is stimulated by the steep surface gradients created by the lower base level as the rift opens up. Mass wasting and rivers with steep gradients carve a coastal lowland and valleys into the upland rim. A seaward-facing escarpment forms at the drainage divide. Preexisting rivers may keep pace with the uplift and traverse the escarpment and allow dissection to spread behind the escarpment. Subsidiary erosion surfaces may form in response to lithological contrasts in rock type and in response to secondary faults that develop parallel to the coast. Observations on other Gondwanan margins suggest that most erosion occurs within 10-20 million years of the rift opening up (Persano et al., 2002). Subsequently, cooling and crustal flexure may cause subsidence and the seaward ends of the valleys are flooded by the sea.

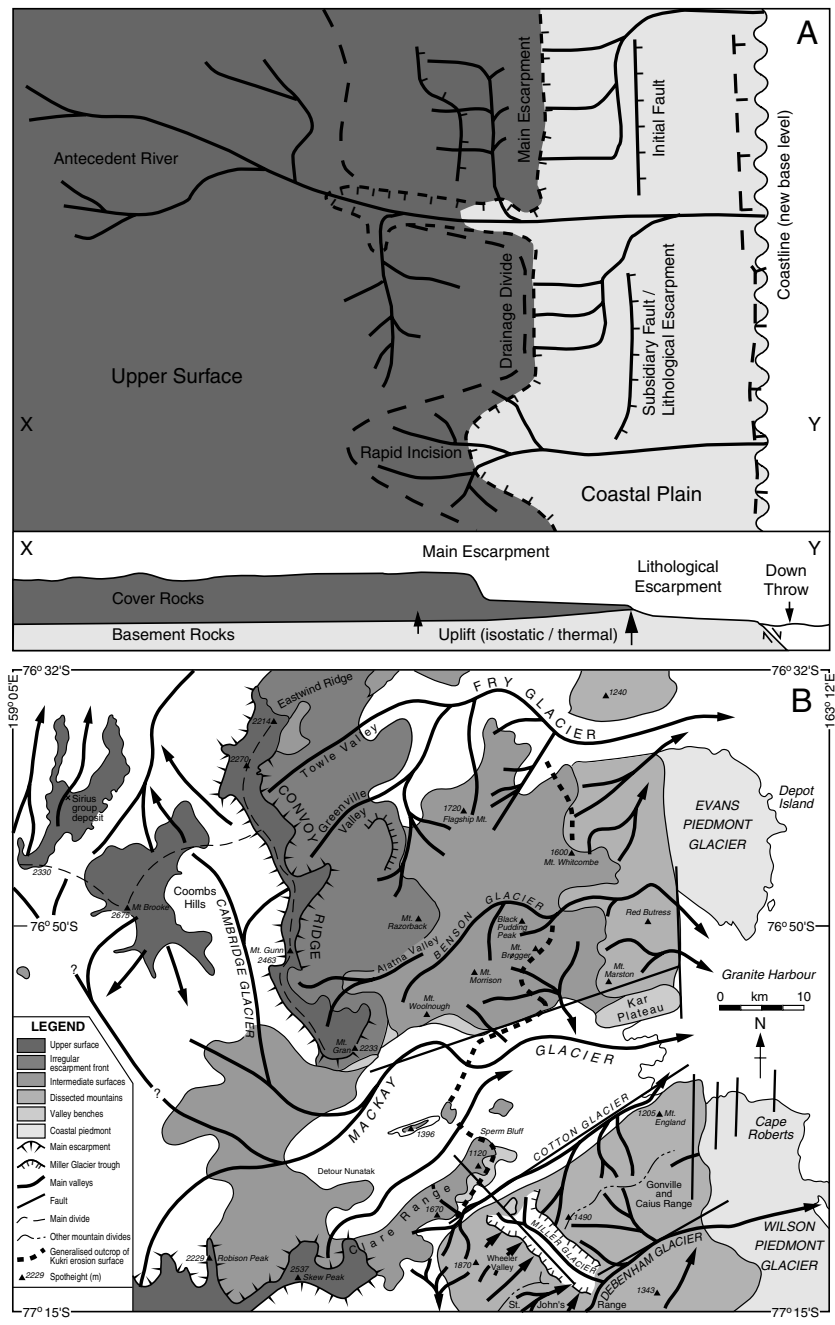

FIGURE 2 (A) Typical landscapes of a passive continental margin as modeled by Beaumont et al. (2000), using a numerical coupled tectonic-earth surface process model of landscape evolution. The new base level creates a pulse of erosion and associated rock uplift that leads to a staircase of coastal erosion surfaces separated by escarpments and incised river valleys, some of which may maintain their valleys across the escarpment crest. (B) Geomorphic map of the Convoy Range and Mackay Glacier area, showing the staircase of seaward-facing escarpments, erosion surfaces, dissected mountain landscapes near the coast, and the dendritic valley patterns radiating from a high point in the Coombs Hills. Principal faults parallel to and at right angles to the mountain front are taken from Fitzgerald (1992).

SOURCE: Sugden and Denton (2004). The model in (A) simulates the field evidence in remarkable detail. 
The model applies to idealized young rift margins, and there are often more complex relationships affecting other continental margins of Gondwana (Bishop and Goldrick, 2000). Factors such as time elapsed since rifting, proximity to the rift, inherited altitude of the margin, tectonic downwarping, and crustal flexure can all affect the amplitude of the topography and the evolution of any escarpment.

\section{Antarctic Evidence}

Figure 3 shows a reconstruction of the continental river patterns inferred to exist if the Antarctic ice sheet is removed and the land compensated for isostatic depression by full flexural rebound. The map is based on the BEDMAP reconstruction of subglacial topography with a nominal resolution of $5 \mathrm{~km}$ (Figure 4) (Lythe et al., 2001). Sea level is assumed to lie at $-100 \mathrm{~m}$ to represent the subsidence associated with the crustal cooling and flexure of mature passive continental margins. The reconstruction is based on hydrological modeling methods for cell-based digital elevation models whereby water is deemed to flow to the lowest adjacent cell. There are many uncertainties, not the least of which is that large areas have little data, but a sensitivity analysis suggests that models forced by a range of different assumptions yield a network that is essentially similar from run to run (Jamieson et al., 2005). The reconstruction shows that there are integrated networks leading radially to major depressions at the coast, such as the western Weddell Sea, Lambert, Wilkes Land, and Oates Land basins. The dendritic pattern of the network, the centripetal pattern of flow from the subglacial Gamburtsev Mountains, and the topological coherence of the tributaries are demonstrated by bifurcation ratios that are representative of other river basins, such as the Orange River in South Africa (Jamieson et al., 2005). These observations imply a fluvial signature in the subglacial landscape on a continental scale.

Such a conclusion is reinforced by investigation of the valley patterns on mountain areas rising above the present ice-sheet surface. Good examples of former fluvial valley systems now occupied by local glaciers exist in the Transantarctic Mountains. The valley networks of several basins in northern Victoria Land have been ordered according to fluvially based Horton-Strahler rules (Horton, 1945; Strahler, 1958) and the dendritic pattern and hierarchical relationships between valley segments, and variables such as cumulative mean length are typical of river networks (Baroni et al., 2005). The Royal Society Range shows a similarly dendritic network radiating from one of the highest summits in Antarctica at over $4000 \mathrm{~m}$ (Sugden et al., 1999).

The landforms near the coast of the Antarctic passive continental margin are well displayed in the relatively glacier-free area of the Dry Valleys and adjacent Convoy Range (Figure 2B). Many features expected of a fluvial landscape are present. These include erosion surfaces rising inland from
FIGURE 3 Reconstruction of the continental-scale river patterns beneath the present ice sheet. We assume that the land is isostatically compensated and that sea level is $100 \mathrm{~m}$ lower than today. The model uses the BEDMAP subglacial topography at a nominal cellular scale of $5 \mathrm{~km}$ (Figure 4). BEDMAP data are from Lythe et al. (2001).

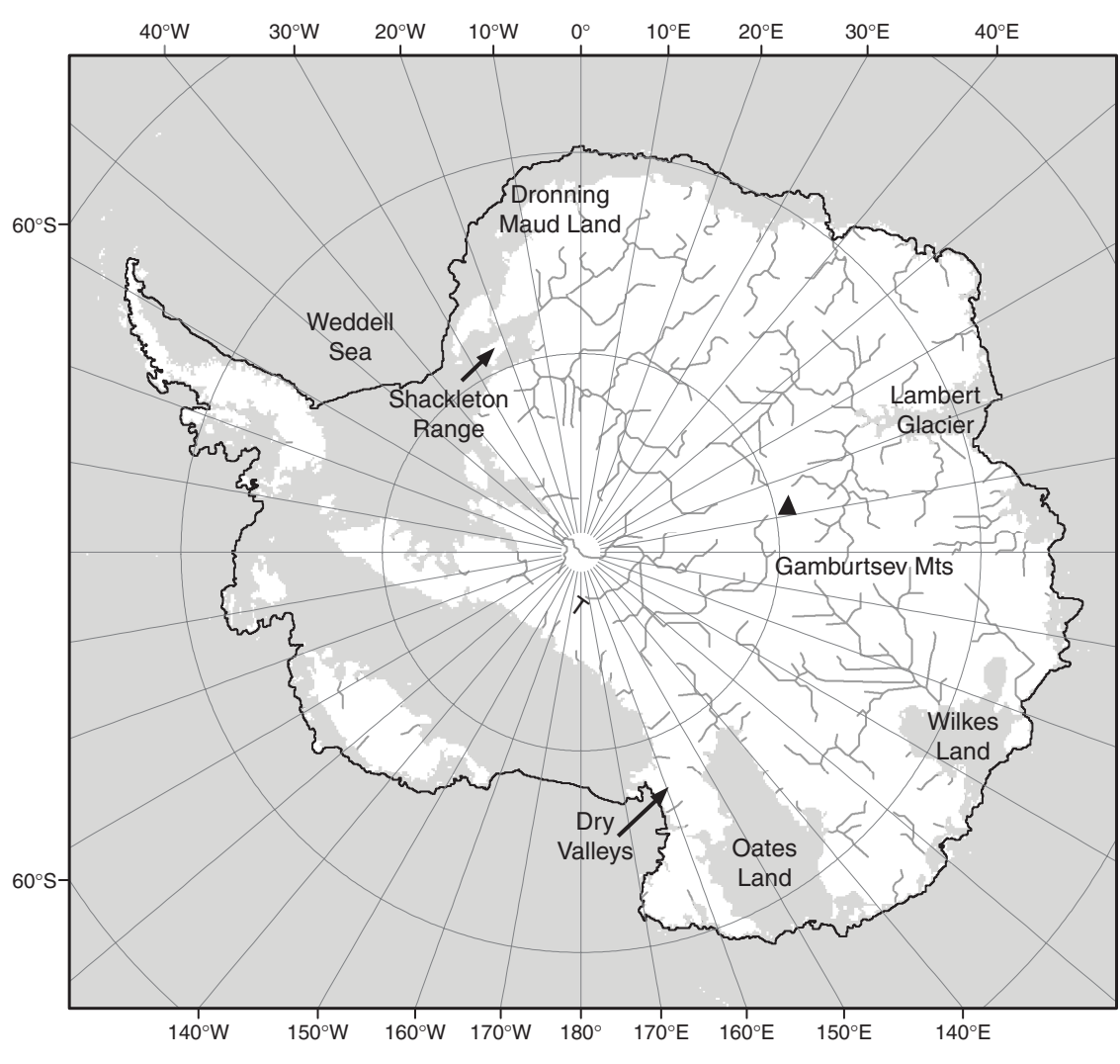




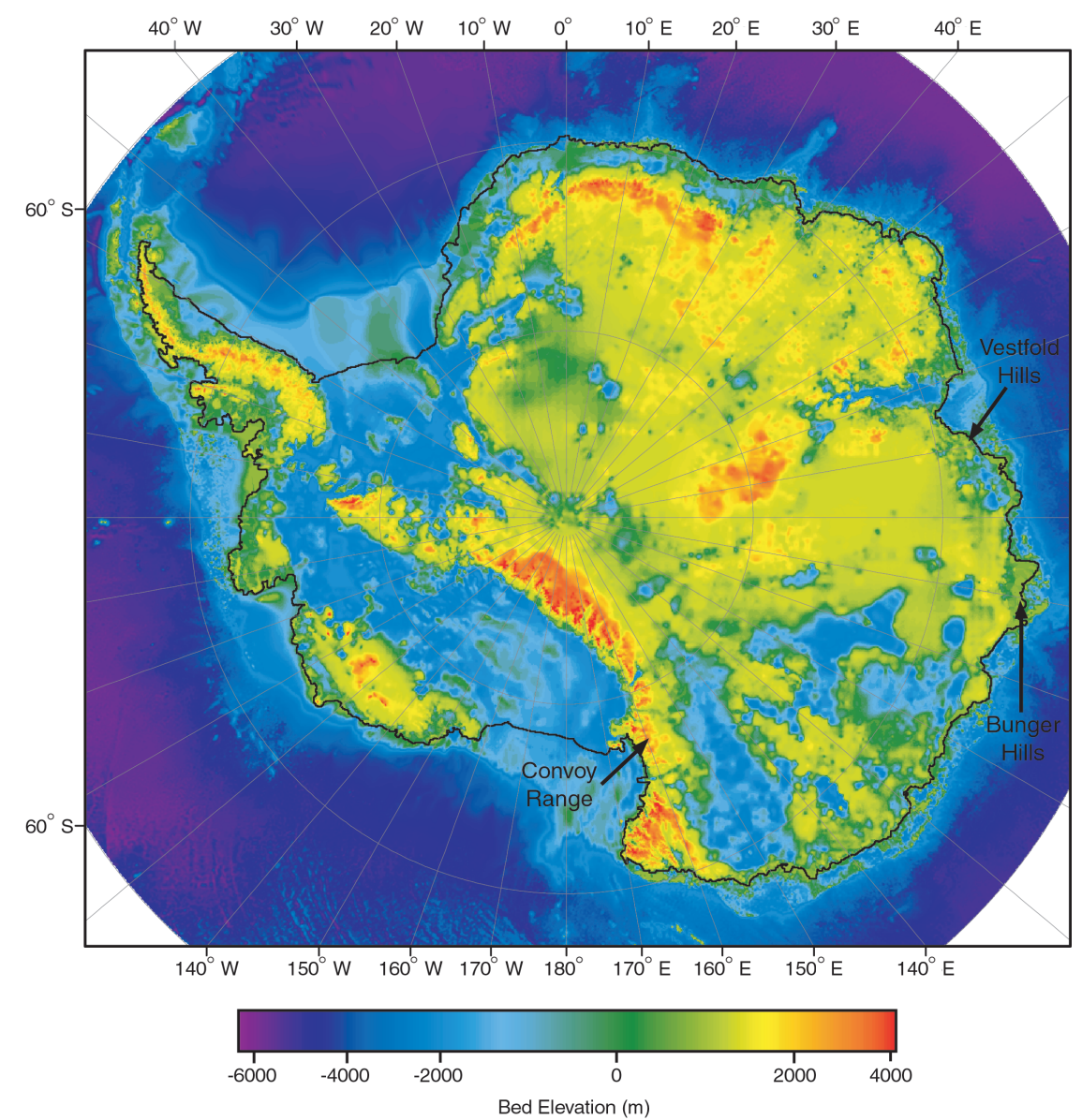

FIGURE 4 The present-day subglacial topography of Antarctica. BEDMAP data are from Lythe et al. (2001). the coast and separated by escarpments, a coastal piedmont, an undulating upper erosion surface dotted with 100-450 m inselbergs, a seaward-facing escarpment 1000-1500 m in height, and intermediate erosion surfaces delimited by lithological variations, notably near horizontal dolerite sills. Sinuous valleys with a dendritic pattern can also be found. Most run from the escarpment to the sea, but others, such as that occupied by Mackay Glacier, breach the escarpment and drain the interior through tributaries bounded by additional escarpments. In detail the valleys have a sinuous planform, rectilinear valley sides with angles of $26-36^{\circ}$, and often lower-angle pediment slopes in the valley floors (Figure 5). The floor of the southernmost Dry Valley, Taylor Valley, is below sea level toward the coast, where it is filled with over $300 \mathrm{~m}$ of sediments of late-Miocene to recent age (Webb and Wrenn, 1982).

The erosion of the coastal margin has been accompanied by the denudation of a wedge of rock thickest at the coast and declining inland. This is displayed in the coastal upwarping of basement rocks and in the denudation history indicated by apatite fission track analysis. Both lines of evidence agree and point to the denudation since rifting of $4.5-5 \mathrm{~km}$ of rock at the coast falling to $\sim 1 \mathrm{~km}$ of rock at locations $100 \mathrm{~km}$ inland (Fitzgerald, 1992; Sugden and Denton, 2004). The fission track analyses suggest that most denudation occurred shortly after 55 Ma.

The evidence presented above is powerful affirmation that the normal fluvial processes of the erosion of a passive continental margin explain the main landscape features of three mountain blocks of the Transantarctic Mountains extending over a distance of $260 \mathrm{~km}$. In these cases it is the fault pattern and the position of the drainage divide that are the main controls on topography and determine the differences in the landscapes of each block. It is not possible to apply the model of passive continental margin evolution to other sectors of East Antarctica without more detailed evidence, but similar landscapes occur in the Shackleton Range (Kerr and Hermichen, 1999) and in Dronning Maud Land (Näslund, 2001). One exception is the Bunger Hills and Vestfold Hills sector of East Antarctica east of the Lambert Glacier, where there is no escarpment. The matching piece of Gondwana is India, which separated early, and a longer and more complex evolution of the rift margin may explain the lack of an escarpment today.

It seems reasonable to argue that the framework of passive continental margin evolution applies to Antarctica and that in many areas a major pulse of fluvial erosion and accompanying uplift was a response to new lower base levels 


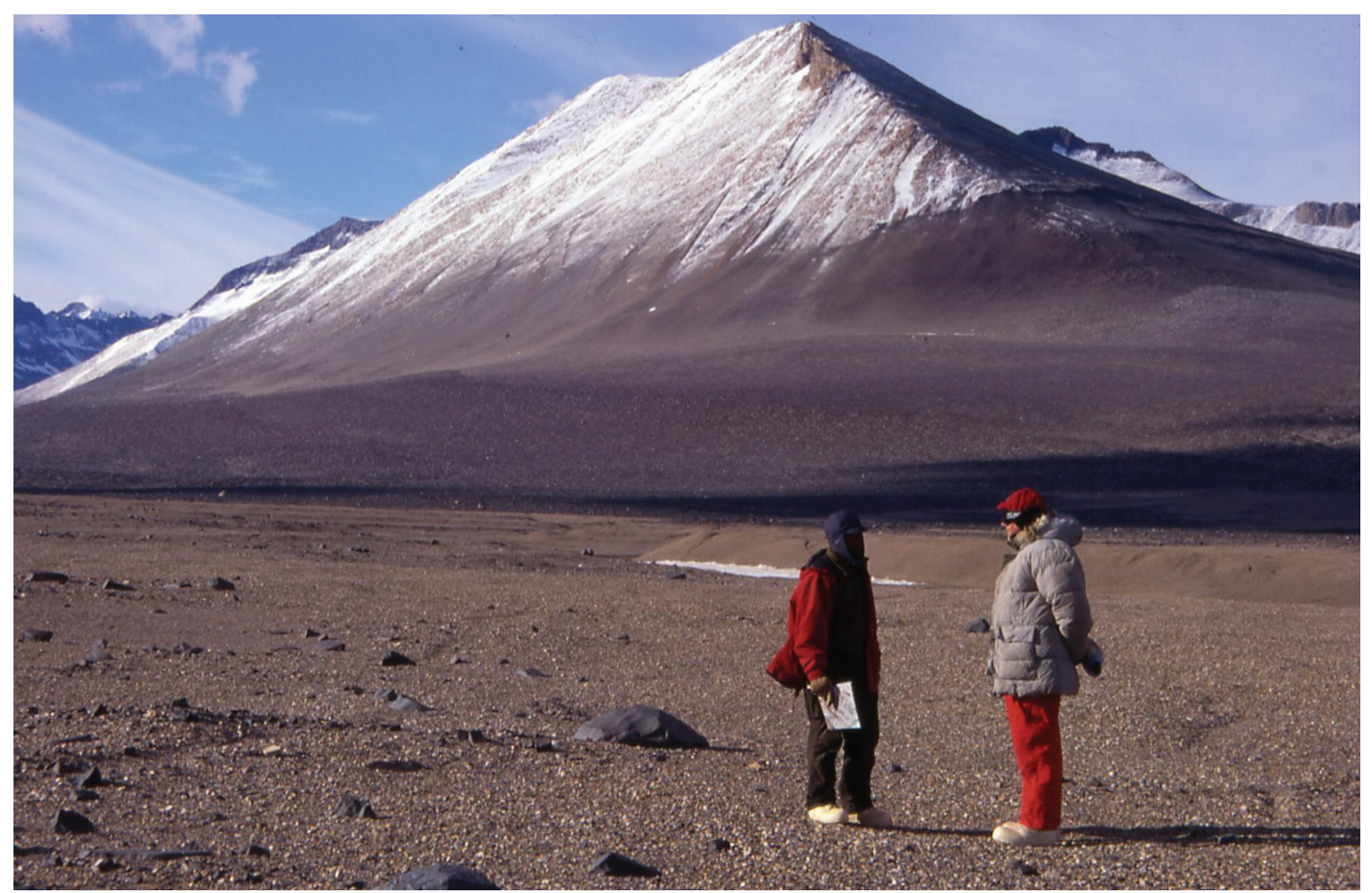

FIGURE 5 George Denton and David Marchant in Victoria Valley, Dry Valleys, a typically fluvial landscape with rectilinear slopes and a shallow pediment slope leading to the valley axis. The slopes have escaped modification by overriding ice.

following continental breakup. Since breakup took place at different times, the stage of landscape evolution will vary from place to place in Antarctica. Furthermore, where largescale tectonic features such as the Lambert graben disrupt the continental margin, they are likely to focus the fluvial system in a distinctive way (Jamieson et al., 2005).

\section{LANDSCAPE EVOLUTION: THE GLACIAL SIGNAL}

\section{Hypothesis}

The beds of former Northern Hemisphere mid-latitude ice sheets form the basis of understanding how glaciers transform preexisting landscapes. There are differences in that the Antarctic ice sheet has existed for tens of millions of years rather than a few million, but there are important similarities in that the North American ice sheet was of similar size and volume as the Antarctic ice sheet, and in that both have fluctuated in size in response to orbital forcing during their evolution, albeit to varying extents.

At the outset it is helpful to distinguish two scales of feature: Those that reflect the integrated radial flow of the ice sheet at a continental scale when it is close to or at its maximum and those that reflect the local and regional flow patterns as ice flows radially from topographic highs.

The key to landscape change by large ice sheets is the superposition of a continental-scale radial flow pattern on the underlying topography. Such patterns are easily obscured by local signals but one can identify the following:

- Erosion in the center and wedges of deposition beneath and around the peripheries (Sugden, 1977; Boulton, 1996);

- Continental shelves that are deeper near the continent and shallower offshore as a result of erosion near the coast, often at the junction between basement and sedimentary rocks (Holtedahl, 1958);

- Radial pattern of large $10-\mathrm{km}$-scale troughs that breach and dissect the drainage divides near the coast and may continue offshore (e.g., in Norway, Greenland, and Baffin Island) (Løken and Hodgson, 1971; Holtedahl, 1967);

- Radial pattern of ice streams with beds tens of $\mathrm{km}$ wide, streamlined bedforms in bedrock and drift, and sharply defined boundaries (Stokes and Clark, 1999); and

- Radial pattern of meltwater flow crossing regional interfluves, as revealed, for example, by the pattern of eskers in North America (Prest, 1970).

Local and regional patterns also display radial configurations and reflect multiple episodes of reduced glaciation. Distinguishing features of marginal glaciation are corries or cirques, the dominant orientation of which, northeast facing, 
is determined in the Northern Hemisphere by slopes shaded from the sun and subject to wind drift by prevailing westerly winds (Evans, 1969). Stronger local glaciation typically builds ice caps on mountain massifs with ice flow carving a radial pattern of troughs, so well displayed in the English Lake District and Scotland, for example.

Clearly there will be a complex interaction between local, regional, and continental modes of flow depending on such factors as climate, ice extent, and topographic geometry. We attempt to model this complexity in Figure 6 by showing various stages of evolution of the Antarctic ice sheet using GLIMMER, a three-dimensional thermomechanical icesheet model as described by Payne (1999) and Jamieson et al. (forthcoming). The intention is to illustrate the range of different ice-sheet geometries that would be expected at various stages of Croll-Milankovitch glacial-deglacial cycles. The model is run for an arbitrary 1 million years with stepped temperature changes every $50 \mathrm{kyr}$ falling from present-day Patagonian values to present-day Antarctic values. This timescale is designed to allow the ice to achieve approximate equilibrium at all times and to allow the isostatic response of the bedrock to reach a balance with these fluctuations in ice thickness. Patagonian climate statistics are used to simulate the climate inferred from vegetation associated with the initial glaciation of Antarctica (Cape Roberts Science Team, 2000; Raine and Askin, 2001). Modeled precipitation follows the pattern of net surface mass balance derived by Vaughan et al. (1999). At the beginning of the model run, maximum coastal precipitation at sea level is scaled up to 2 $\mathrm{m}$ per year, four times that of the present day. The maximum then falls linearly to $0.5 \mathrm{~m}$ per year by the end of the model run. Mean annual temperatures fall from $7^{\circ} \mathrm{C}$ at sea level to present values of $-12^{\circ} \mathrm{C}$ through the model run. Melt rates under warmer climatic conditions are calculated using a positive degree-day model (Reeh, 1991) whereby ablation is proportional to the number of days where temperature is above the freezing point. Diurnal variability is accounted for by using a normal distribution of temperature with a $5^{\circ} \mathrm{C}$ standard deviation. The pattern of mass balance used to drive ice growth is shown in Figure 7.

The bed topography is derived from BEDMAP (Figure 4) (Lythe et al., 2001) and is flexurally rebounded to compensate for the lack of an ice sheet. The use of an isostatically compensated present-day topography ignores tectonic movements and means that the results of the modeling become more uncertain as one goes further back in time. However, there is less risk in East Antarctica, where the main topographic features were established by Oligocene times. For example, geological evidence in the form of basement clasts in Oligocene strata cored off the Victoria Land coast (CIROS-1 drillcore) (Barrett et al., 1989) and Cape Roberts (Cape Roberts Science Team, 2000) suggests that the Transantarctic Mountains had been eroded deep enough to form a significant feature by Oligocene times. Furthermore, the Gamburtsev Mountains are considered to be a Pan-African feature with an age of $500 \mathrm{Ma}$ (van de Flierdt et al., 2007).

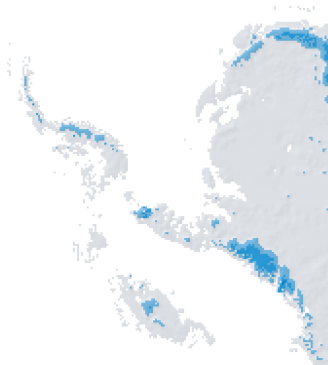

A

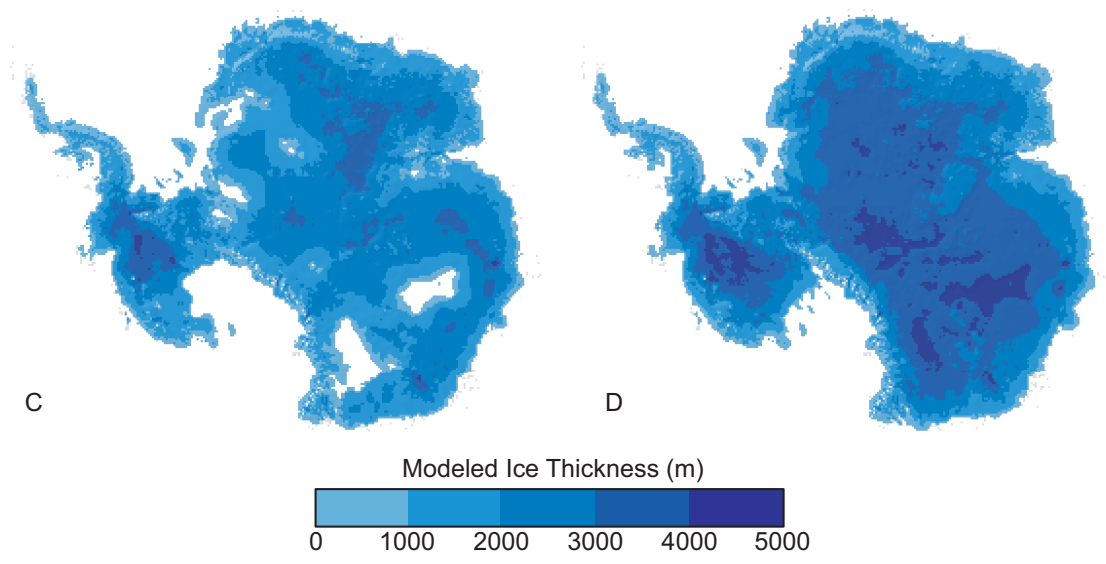

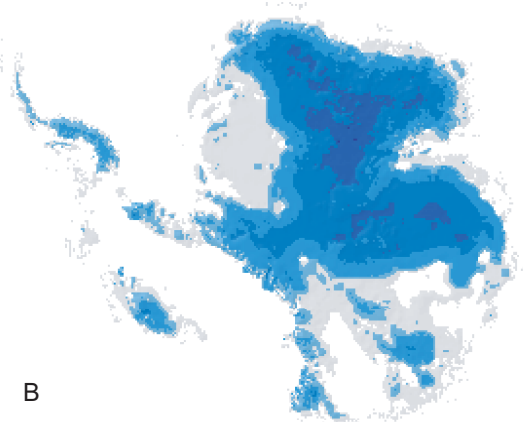

FIGURE 6 Model of the Antarctic ice sheet, generated using the GLIMMER 3-D thermomechanical model and the stepped transition from a Patagonian-style climate to the present polar climate. The four stages (A-D) illustrate the range of variability to be expected as the Antarctic ice sheet experienced many Croll-Milankovitch glacial cycles during its early evolution. 


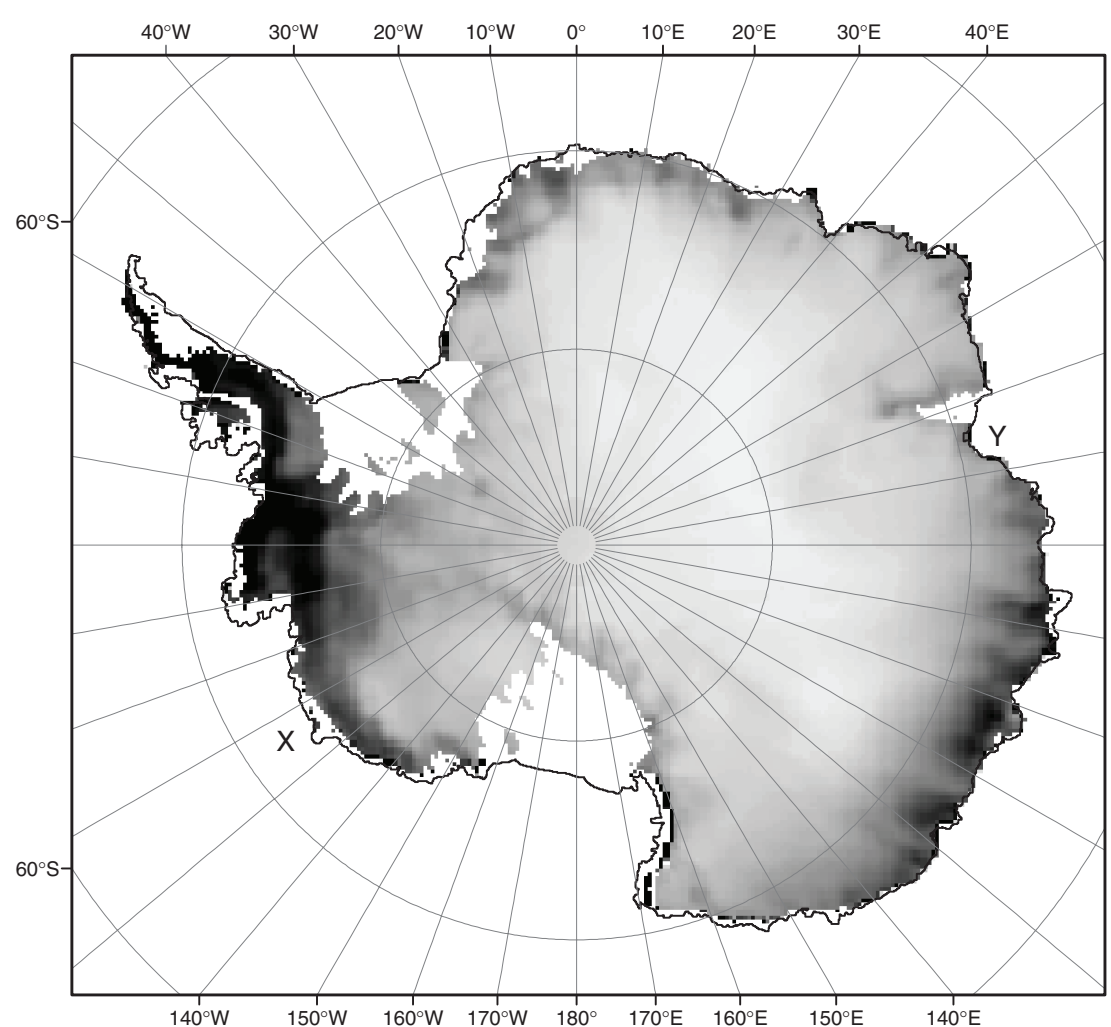

FIGURE 7 Present-day accumulation is used to drive a simulated Antarctic ice sheet (Vaughan et al., 1999). Profile X-Y shows that under a Patagonian-style regime (grey line) there are zones of increased accumulation at high altitudes. Accumulation is discontinuous because of high levels of ablation across much of the continental lowlands. The present-day accumulation is shown by the black line.

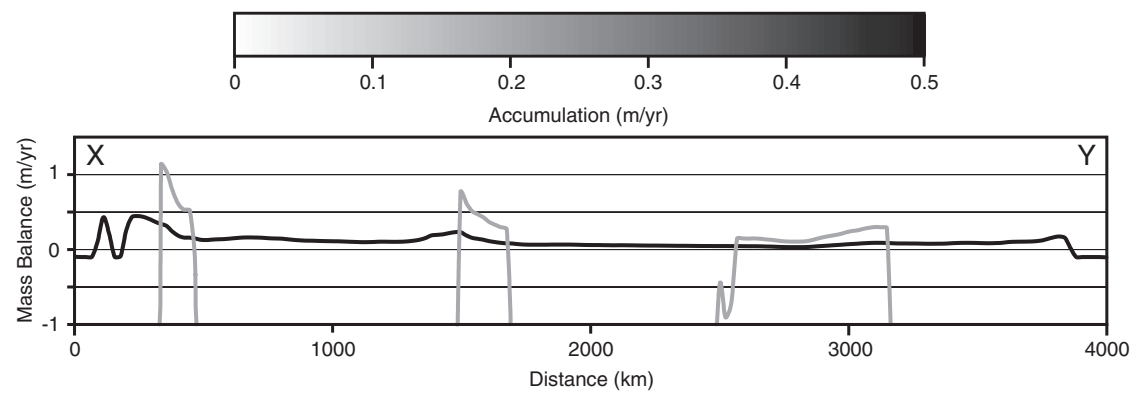

The different stages of growth illustrate the principal pattern of glaciation of Antarctica. Initial growth is in coastal mountains, such as in Dronning Maud Land, along the Transantarctic Mountains, in the West Antarctic archipelago, and in the high Gamburtsev Mountains in the interior. The ice spreads out from these mountain centers, first linking the main East Antarctic centers and then the West Antarctic centers. The model is deliberately simple but it suffices to show that glaciation starts preferentially in maritime mountains and in interior mountains if they are high enough. It also serves to illustrate the complexity of the changing pattern of flow as different ice centers merge and ice flow evolves from locally radial to continentally radial. The subglacial landscape of Antarctica can be expected to consist of a palimpsest of landforms related to these local, regional, and continental stages, while eroded material will experience a complex history of temporary deposition and changing flow paths before being delivered to the coastal margin by the continental ice sheet.

\section{Antarctic Evidence}

The evidence of continental radial patterns of erosion is spectacular. The Lambert trough, which is $40-50 \mathrm{~km}$ across and $1 \mathrm{~km}$ deep, drains 10 percent of the East Antarctic ice sheet. It is coincident with a graben and is comparable to, but deeper and longer than, the North American equivalents, such as Frobisher Bay in Baffin Island. And then there is the spectacular series of troughs cutting through the Transantarctic Mountain rim. Webb (1994) has previously suggested that the Beardmore trough, $200 \mathrm{~km}$ long, 15-45 km wide, and over $1200 \mathrm{~m}$ deep, exploited a preexisting river valley. Unloading due to glacial erosion may have contributed to isostatic uplift of the adjacent mountains (Stern et al., 2005). Offshore there are continuations of such troughs incised 
into the continental shelf of both East and West Antarctica (Wellner et al., 2001). Other troughs, such as that running parallel to Adelaide Island on the Antarctic Peninsula, have exploited the junction between basement and sedimentary rocks (Anderson, 1999). A series of ice streams flow into the Ross Sea and Weddell Sea embayments. They are underlain by deformable till and, in the case of the Rutford ice stream, by streamlined bedforms (Smith et al., 2007). There is also growing evidence of radial outflow of basal meltwater (Evatt et al., 2006). Hundred-meter-deep rock channels and massive staircases of giant potholes represent large-scale outbursts of subglacial meltwater across the Transantarctic Mountains rim in the McMurdo area (Denton and Sugden, 2005; Lewis et al., 2006).

There is also evidence of local and regional glacial landforms. Early studies of the subglacial Gamburtsev Mountains revealed characteristic trough overdeepening and the presence of hanging valleys, pointing to a local glaciation (Figure 8). The glacial landscapes of Dronning Maud Land too were created by local mountain glaciation and not the present ice sheet (Holmlund and Näslund, 1994). Recent geophysical surveying has demonstrated the presence of lakes in overdeepened troughs radiating from the Ellsworth Mountain core (Siegert, pers. comm., 2007). Overdeepening in the topographically constrained part of a fjord, and the rock threshold at the point when the trough opens out, are well-known characteristics of fjords in the Northern Hemisphere (Løken and Hodgson, 1971; Holtedahl, 1967). Similar features are found to radiate from uplands now below sea level in the Ross Sea embayment (De Santis et al., 1995;
Sorlien et al., 2007). In these latter cases the troughs are revealed by seismic survey. In the McMurdo Dry Valleys area of the Transantarctic Mountains a phase of local glaciation is represented by troughs identified on the inland flank of the mountains (Drewry, 1982) and troughs exploiting sinuous river valleys, such as the Mackay Glacier. Finally, the compact wet-based glacial deposits (the Sirius Group deposits) distributed at high elevations along $1000 \mathrm{~km}$ of the Transantarctic Mountains in the Ross Sea sector represent glaciation centered on the mountains (Denton et al., 1991, 1993). The deposits are characterized by local lithologies and the till components contain striated stones and a matrix typical of glacial erosion under warm-based ice. Some of these deposits incorporate remains of Nothofagus (southern beech) forest representative of a cool temperate environment.

\section{LANDSCAPE EVOLUTION: THE COMBINED SIGNAL}

\section{Hypotheses}

It is possible to relate subglacial landscapes to the processes by which glaciers modify preexisting topography. A simple classification scheme recognizes landscapes of areal scouring with abundant evidence of glacial scour; those of selective linear erosion where troughs dissect plateaus; those with no sign of glacial erosion and devoid of glacial landforms; and depositional landscapes composed of till and meltwater deposits (Sugden, 1978). The differences are related to whether the basal ice is at the pressure melting point. A key assumption is that ice erodes effectively when the base

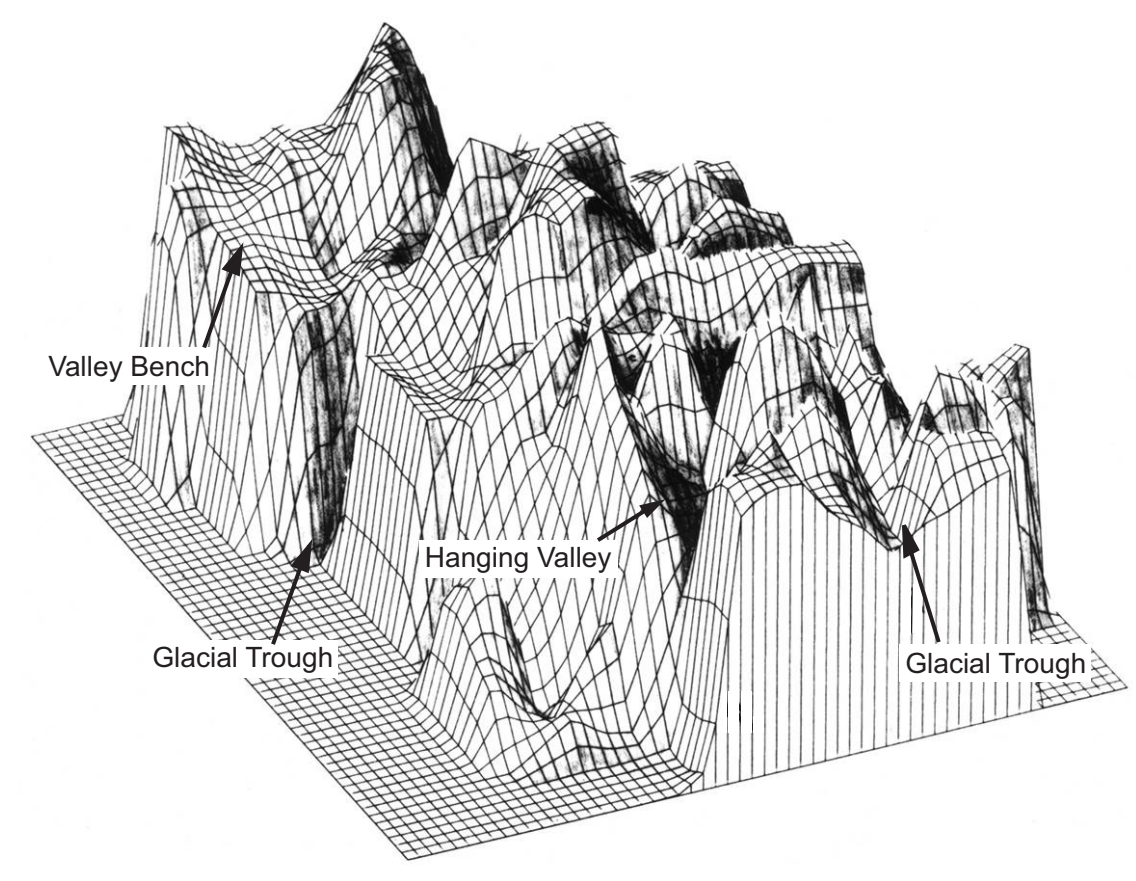

FIGURE 8 An early reconstruction of the landscape of the subglacial Gamburtsev Mountains based on the analysis of radioecho sounding data. The arrows pick out diagnostic glacial features such as overdeepening and hanging valleys presumed to have been formed by local mountain glaciation (modified from Perkins, 1984). 
is at the pressure melting point because sliding takes place between the ice and bedrock, permitting several processes to entrain bedrock and to deposit material. Such a situation explains landscapes of areal scouring, the linear erosion of troughs, and zones of deposition. The converse is that when the basal temperature is below the pressure melting point there is no sliding at the ice and rock interface. In such situations ice can be essentially protective and leave little sign of erosion. There is debate as to how protective the ice may be (Cuffey et al., 2000), but recent work on cosmogenic isotope analysis demonstrating the age of exposure and the time buried beneath ice has shown that the hypothesis holds in many areas of the Northern Hemisphere (Briner et al., 2006; Stroeven et al. 2002).

Armed with these observations it is possible to hypothesize about the landscape beneath the Antarctic ice sheet and suggest local, regional, and continental patterns. The numerical model of ice-sheet growth can be used to predict the changing pattern of glacial erosion during glacial cycles. Figure 9 shows the distribution of basal ice at the pressure melting point during stages of regional and continental glaciation. The regional pattern shows how the peripheries of the regional ice sheets are warm-based near their margins and inland to the vicinity of the equilibrium line where the ice discharge is highest and generating most internal heat. These will be the areas of glacial erosion. The influence of topography is clear in that warm-based ice is focused on the depressions and major valleys where ice is thicker and flows faster. These low-lying areas at the pressure melting point are also those in which subglacial lakes might accumulate. What is striking is the way this zone of peripheral warm-based ice and erosion is a wave that sweeps across the landscape as the ice sheet grows to its continental maximum. At the macroscale the zone of warm-based ice is more extensive around the continental margins, especially in the vicinity of the main preexisting drainage basin outlets. Under both scenarios the ice over the main uplands remains below the pressure melting point.

From the above we can predict that the landscape in lowland areas of the Antarctic ice sheet will be underlain by a landscape of areal scouring. This relates both to the presence of ice at the pressure melting point and to the progressive erosion of rock debris by radial outflow of ice at different scales. Interaction between local and ice-sheet maximum flow directions and rock structure will determine the roughness and degree of streamlining of landforms. Flow in the same direction under both local and continental modes will favor elongated streamlined bedforms, perhaps with plucked
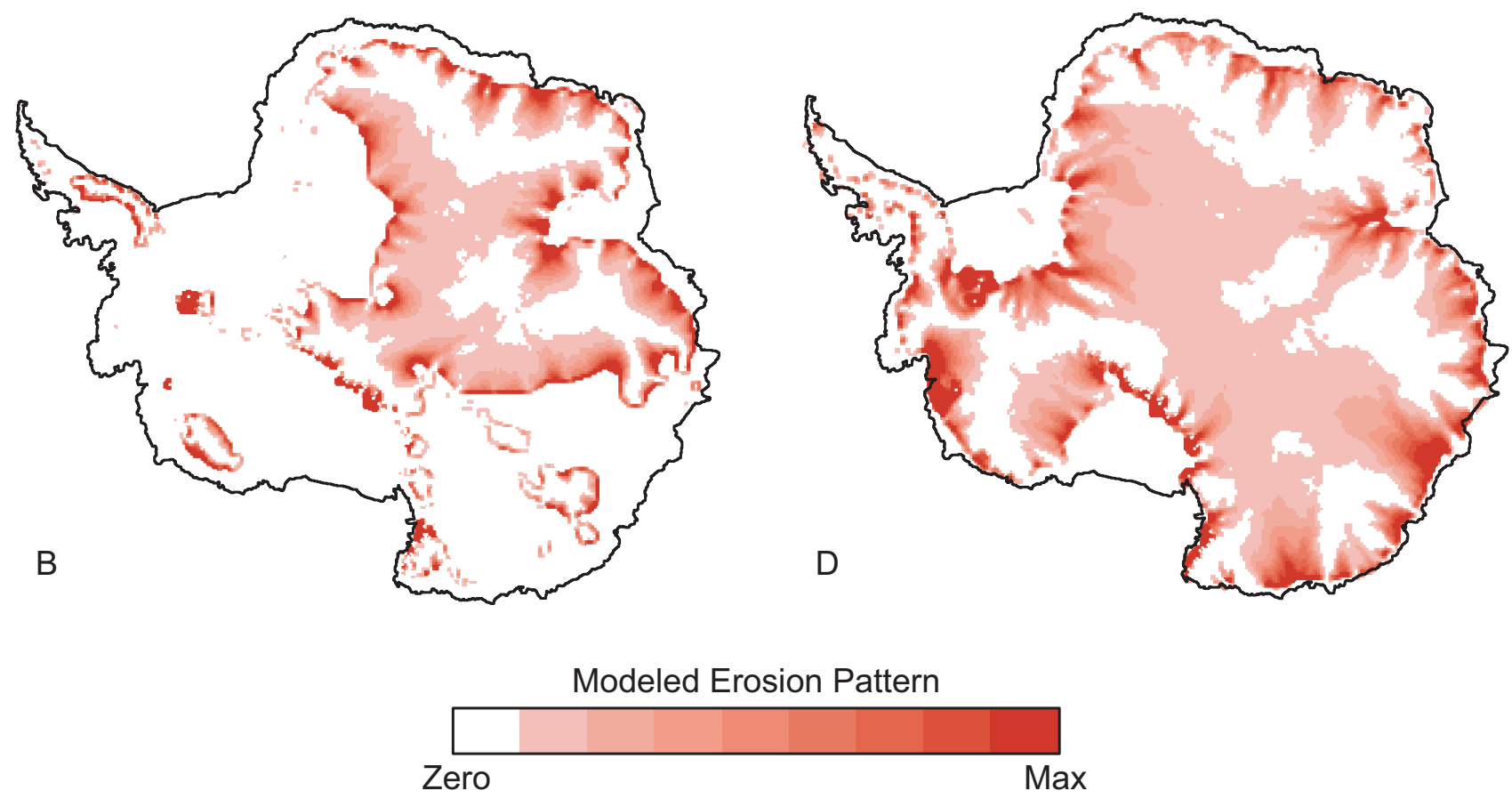

FIGURE 9 Modeled distribution of basal ice at the pressure melting point during intermediate and full stages of Antarctic glaciation (letters correspond to snapshots in Figure 6). Erosion, thought to be associated with sliding under such basal conditions, is concentrated toward the ice-sheet margins and at the beds of major outlet glaciers. A wave of erosion accompanies the expansion of local and regional ice to a full continental ice sheet. 
lee slopes, while complex flow changes will leave an irregular pattern. Areal scouring will be clearest on the lowlands and diminish upslope on upstanding massifs where summits may show no sign of glacial modification. This latter pattern reflects the effects of topography on the basal thermal regime and implies that the ice remained cold-based during local, regional, and continental stages of glaciation. Judging by the geomorphology of glaciated shields of the Northern Hemisphere, erosion will have removed some tens of meters of material, much of it initially as weathered regolith. This is sufficient to modify but not erase the preexisting river landscape, as argued for northern Europe (Lidmar-Bergstrom, 1982). However, given the longer duration of glaciation in Antarctica one would expect a greater depth to have been removed. The products of this erosion will be deposited offshore.

\section{Antarctic Evidence}

There is no direct evidence of areally scoured landscapes beneath the ice sheet. However, there are many observations from around the margins of Antarctica to indicate that such landscapes are likely to be widespread. Areas formerly covered by an earlier expanded ice sheet display extensive landscapes of areal scouring. This includes oases in East Antarctica, such as the Amery Oasis bordering the Lambert Glacier (Hambrey et al., 2007); the Ross Sea area where the scouring is most prominent near sea level and can be traced to elevations of 1000-2100 $\mathrm{m}$ along the Transantarctic Mountains front (Denton and Sugden, 2005); the inner parts of the offshore shelf in many parts of West Antarctica; and the offshore shelves surrounding islands off the Antarctic Peninsula and sub-Antarctic islands (Anderson, 1999). In all these situations meltwater channels testify to the activity of basal meltwater. Whereas all these observations are consistent with the view that warm-based ice occurred beneath thicker parts of the ice sheet when it was more extended and in maritime environments, what is surprising is that striated, scoured rock surfaces also define trimlines around mountains protruding above the ice sheet, even in the interior, such as the Ellsworth Mountains (Denton et al., 1992). The implication of shallow surface ice at the pressure melting point is that surface climatic conditions must have been within a few degrees of freezing point and thus several tens of degrees warmer than at present.

Landscapes of selective linear erosion are common in the mountainous rim of East Antarctica. In many areas glacial troughs are clearly delimited and excavated into a landscape-preserving fluvial valley form, often bearing diagnostic subaerial weathering forms such as regolith and tors. Such a description would apply to the landscapes bordering the Lambert Glacier (Hambrey et al., 2007), the Shackleton Mountains (Kerr and Hermichen, 1999), exposed escarpments in Dronning Maud Land (Näslund, 2001), the mountain blocks of the Transantarctic Mountains in Victoria
Land (Sugden and Denton, 2004), and the plateaus of the Antarctic Peninsula area (Linton, 1963). As in the Northern Hemisphere such a description also applies on the scale of individual massifs. For example, upstanding nunataks in the Sarnoff Mountains of Marie Byrd Land are bounded by lower slopes with clear evidence of glacial scouring and yet their summits have retained an upper surface with tors, weathering pits, and block fields. In this case cosmogenic isotope analysis demonstrates that the mountains have been covered by ice of several glacial maxima and that weathering has continued sporadically in interglacials for $\sim 1$ million years (Sugden et al., 2005). The selectivity reflects the difference between the thicker, converging ice that scours as it flows round the massif and the thin diverging ice covering the summit that remains cold-based during each episode of overriding.

The implication of the above is that the hypothesis relating glacial modification of a preexisting landscape to the presence or absence of warm-based ice may be helpful in describing and understanding the landscape evolution of Antarctica. When the basal thermal regime remains the same beneath both local and full ice-sheet conditions, then the glacial transformation, or lack of it, will be clearest. What is exciting about the present time is that cosmogenic isotope analysis offers the opportunity to quantify such relationships.

\section{CHRONOLOGY OF LANDSCAPE EVOLUTION}

A number of dates help firm up the relative chronology of landscape evolution. Early studies of offshore sediments in Prydz Bay established the presence of fluvial sediments below the earliest glacial sediments, the latter dated to $\sim 34$ Ma (Cooper et al., 1991; O'Brien et al., 2001). The location, structure, and nature of the sediments suggest that the deposits have been derived from rivers flowing along the Lambert graben. Probably the deposits began to accumulate when rift separation began around $118 \mathrm{Ma}$ (Jamieson et al., 2005).

Some large glacial troughs were cut by late Miocene times. In the Lambert Glacier area the offshore sedimentary evidence points to an ice sheet that discharged from a broad front on the offshore shelf until the late Miocene but experienced a switch to deposition within the overdeepened Lambert glacial trough subsequently. Ice-sheet modeling suggests that the deepening of the trough changed the dynamics of glacier flow and ablation to such an extent that calving velocity could match ice velocity and that the glacier was no longer able to advance through the deep water of the trough (Taylor et al., 2004). The implication is that the trough was excavated deeply by the late Miocene. Similar relationships occur in the glacially deepened mouths of the Dry Valleys in the McMurdo Sound area. Microfossils at the bottom of the Dry Valleys Drilling Project (DVDP-11) drillcore at the mouth of Taylor Valley are late Miocene in age (Webb and Wrenn, 1982). Marine shells deposited in a fjord in the glacial trough of Wright Valley are Pliocene in 
age and overlie a till of $>13.6 \mathrm{Ma}$ (Hall et al., 1993). These age relationships in glacial troughs related to ice flow from the interior of Antarctica demonstrate that they were cut by the late Miocene.

There is evidence from the McMurdo Sound area that the Antarctic ice sheet overrode marginal mountains and extended to the outer shelf at its maximum in the mid-Miocene. The case is argued out in a series of detailed papers in the Dry Valleys area, the key chronological fixes of which are:

- There is clear evidence that ice overrode all except perhaps the highest mountains in the Royal Society Range in the form of ice scouring on cols and subglacial meltwater channels that cross the mountains. The direction of flow is conformable with models of ice expansion to the outer edge of the offshore shelf (Sugden and Denton, 2004).

- ${ }^{40} \mathrm{Ar} /{ }^{39} \mathrm{Ar}$ dating of in situ volcanic ash deposits overrun by such ice and those ashes deposited on till sheets associated with such overriding ice constrains the event to between 14.8 Ma and 13.6 Ma (Marchant et al., 1993).

- Landscapes of areal scouring molded by the maximum ice sheet in front of the Royal Society are older than $12.43 \pm 0.22 \mathrm{Ma}$, the age of the oldest undisturbed volcanic cone known to have erupted onto the land surface (Sugden et al., 1999).

- ${ }^{40} \mathrm{Ar} /{ }^{39} \mathrm{Ar}$ analyses of tephra show that the major meltwater feature represented by the Labyrinth in Wright Valley predates $12.4 \mathrm{Ma}$ and that the last major outburst occurred some time between 14.4 Ma and 12.4 Ma (Lewis et al., 2006).

- ${ }^{3} \mathrm{He}$ ages of individual dolerite clasts in meltwater deposits from the overriding ice sheet reveal exposure ages between $8.63 \pm 0.09$ and $10.40 \pm 0.04 \mathrm{Ma}$. Allowing for erosion, they are calculated to have been exposed for $\sim 13 \mathrm{Ma}$ (Margerison et al., 2005).

As yet there are few comparable terrestrial dates elsewhere in Antarctica, but it is worth drawing attention to work on the flanks of the Lambert Glacier in which there is biostratigraphical evidence of a pre-late Miocene phase of glacial erosion and deepening, followed by a 10-million-year period of exposure (Hambrey et al., 2007). It is tempting to equate the deepening to the same ice-sheet maximum.

In the McMurdo Sound area it is possible to establish that a phase of warm-based glaciation occurred before the mid-Miocene overriding ice. The critical evidence is that warm-based tills in the high mountains bounding the Dry Valleys, and indeed the Sirius Group deposits, have been modified by overriding ice. Typically there are erosional patches excavated into a preexisting till with material dragged out down-ice (Marchant et al., 1993) and ripple corrugations with a spacing of $25-50 \mathrm{~m}$ that are a coherent part of the overriding meltwater system (Denton and Sugden, 2005). One important fix on the switch from warm-based to cold-based local glaciation has been reported from the Olympus Range in the McMurdo Sound area of the Transantarctic Mountains (Lewis et al., 2007). Here a classic warm-based till with meltout facies is overlain by weathered colluvium that is itself overlain by tills deposited by cold-based glaciers. The minimum date of transition is fixed by volcanic ashes interbedded between the two sets of tills and has an age of 13.94 Ma. Such a transition beneath small local glaciers is argued to represent an atmospheric cooling of $20-25^{\circ} \mathrm{C}$. Moreover, the transition occurs before one or more major ice-sheet overriding events in the same area.

\section{DISCUSSION}

Here we attempt a synthesis of landscape evolution of Antarctica, based mainly on terrestrial evidence (Table 1). Inevitably the hypothesis is based on partial information and is biased toward the data-rich McMurdo Sound area of the Transantarctic Mountains. Nevertheless it seems helpful to try and generalize more broadly.

An early pulse of fluvial erosion was associated with the breakup of Gondwana and the creation of new lower base levels around the separating continental fragments. The timing of the pulse varied with the time of base level change around each segment. Erosion removed a wedge of material from around the margins of East Antarctica and the smaller continental fragments of West Antarctica. Escarpments

TABLE 1 The Chronology of Landscape Evolution in Antarctica Based Mainly on Terrestrial Evidence

\begin{tabular}{|c|c|}
\hline$>55-34 \mathrm{Ma}$ & $\begin{array}{l}\text { Passive continental margin erosion of coastal } \\
\text { surfaces, escarpments, and river valleys, removing } \\
4-7 \mathrm{~km} \text { of rock at the coast and } 1 \mathrm{~km} \text { inland since } \\
\text { rifting. Cool temperate forest and smectite-rich } \\
\text { soils, at least at coast. }\end{array}$ \\
\hline $34 \mathrm{Ma}$ & $\begin{array}{l}\text { Initial glaciation of regional uplands with } \\
\text { widespread warm-based ice, local radial troughs, } \\
\text { and tills. Climate cooling. }\end{array}$ \\
\hline 34-14 Ma & $\begin{array}{l}\text { Local, regional, and continental orbital ice- } \\
\text { sheet fluctuations associated with progressive } \\
\text { cooling, declining meltwater, and change to } \\
\text { tundra vegetation. Local warm-based glaciers in } \\
\text { mountains. }\end{array}$ \\
\hline$\sim 14 \mathrm{Ma}$ & $\begin{array}{l}\text { Expansion of maximum Antarctic ice sheet to edge } \\
\text { of continental shelf linked to sharp temperature } \\
\text { decline of } 20-25^{\circ} \mathrm{C} \text {. Change from warm-based } \\
\text { to cold-based local mountain glaciers. Selective } \\
\text { erosion of continental-scale radial and offshore } \\
\text { glacial troughs and meltwater routes. }\end{array}$ \\
\hline 13.6 Ma to Present & $\begin{array}{l}\text { Ice sheet maintains hyperarid polar climate. Slight } \\
\text { thickening of ice-sheet margins during Pliocene } \\
\text { warming in East Antarctica. Outlet glaciers respond } \\
\text { to sea-level change, especially in West Antarctica. } \\
\text { Extremely low rates of subaerial weathering. } \\
\text { Glacial erosion restricted to outlet glaciers and } \\
\text { beneath thick ice. }\end{array}$ \\
\hline
\end{tabular}


and erosion surfaces formed and were dissected to varying degrees by fluvial erosion. The degree of dissection increased with the complex geometry and small size of each fragment and was more pronounced near the coast. The interior of East Antarctica was characterized by large river basins, presumably more arid in the interior than at the coast. The climate was sufficiently warm to support beech forests around the coast. Soils contained the clay mineral smectite, derived from the chemical weathering associated with forests.

Around $34 \mathrm{Ma}$ declining atmospheric carbon dioxide and the opening of significant seaways between Antarctica and the southern continents were factors in bringing the two conditions necessary for glaciers: cooling and increased precipitation from circumpolar storms. Glaciation began in a Patagonian-type climate, at least in the Transantarctic Mountains, and was centered on maritime mountains of East and West Antarctica and high continental mountains in East Antarctica. The record from the Cape Roberts cores of fluctuating ice-sheet extent, which is supported by marine oxygen isotope records, points to a dynamic ice sheet responding to orbital fluctuations in the same way as the Pleistocene ice sheets of the Northern Hemisphere. The preexisting regolith was progressively removed from the continent to create a subglacial landscape of areal scouring, probably in a complex series of flows as glacier extent and flow directions oscillated between an interglacial and ice-maximum state. Modeling suggests a wave of erosion was associated with each expansion of ice from the mountain centers. The presence of warm-based local glaciers in the Transantarctic Mountains suggests relatively warm interglacial periods.

The terrestrial record agrees with the marine record in pinpointing a sharp temperature decline associated with the expansion of the Antarctic ice sheet over its continental shelf at $\sim 14$ Ma. Perhaps the expansion was triggered by a change in ocean circulation or declining atmospheric carbon dioxide. Perhaps it too could have been related to the internal dynamics of the ice sheet in that earlier glaciations had deposited shoals on the offshore shelf, reduced calving, and allowed the ice to advance to the outer edge, behavior well known in the case of fjord glaciers (Mercer, 1961).

The mid-Miocene maximum ice sheet eroded troughs on a continental-scale, cutting selectively through the mountain rim, deepening the interior parts of the offshore shelf (and subsea basins?) in West Antarctica. Land surfaces covered by thin diverging ice remained essentially unchanged. Perhaps the offshore deepening was such that in cycles of growth and decay the ice could no longer advance to the shelf edge, as demonstrated by the behavior of the Lambert Glacier. Alternatively the change in ocean and atmospheric conditions after the mid-Miocene maximum to a hyperarid polar climate may have deprived the ice sheet of moisture. But after 13.6 Ma the ice retreated to its present continental lair, at least in East Antarctica, and remained essentially intact. Coastal fjords were filled with shallow marine Miocene sediments. The retreat and subsequent stability of the full ice sheet and its associated polar climate is demonstrated on land by the remarkably low erosion rates in the Transantarctic Mountains as revealed by ${ }^{39} \mathrm{Ar} /{ }^{40} \mathrm{Ar}$ dating of volcanic ashes and cones, by cosmogenic isotope analysis, and by the preservation of fragile deposits and buried ice (Brook et al., 1995; Ivy-Ochs et al., 1995; Summerfield et al., 1999; Marchant et al., 2002). Offshore the growth and decay of the maximum ice sheet is demonstrated by a widespread unconformity and dating evidence of a retreat of the ice in the Ross Sea area after 13.5 Ma (Anderson, 1999).

The implication of the above is that fluctuations of the Antarctic ice sheet in the Pleistocene are forced by changes in sea level. In East Antarctica the fluctuations are relatively minor. Outlet glaciers thicken and advance seaward in response to a lowering of sea level in the Northern Hemisphere, as demonstrated in the case of the outlets flowing through the Transantarctic Mountains (Denton et al., 1989). Slight thickening occurs in Mac Robertson Land (Mackintosh et al., 2007), but the ice does not extend far offshore (O'Brien et al., 2001; Leventer et al., 2006). In agreement with such a limited expansion, the coastal oases of the Bunger Hills and the Larsemann Hills appear to have remained ice-free during the last glacial cycle (Gore et al., 2001; Hodgson et al., 2001). In West Antarctica the Pleistocene behavior is markedly different. Here ice appears to have extended to the edge of the continental shelf and occupied deep troughs extending $\sim 100 \mathrm{~km}$ from the present coast (Bentley and Anderson, 1998; Ó Cofaigh et al., 2005). In this case and following Mercer (1978), one can surmise that the grounded ice streams occupying the topography below sea level between the individual massifs are especially susceptible to sea-level changes.

It is interesting that the ice sheet achieved its present profile in Mac Robertson Land 6000 years ago (Mackintosh et al., 2007). This is the time when global sea level had largely completed its recovery following the final disappearance of the North American ice sheet. The coincidence supports the view that Antarctic ice fluctuations in the Pleistocene are a response to sea-level changes driven primarily by the Northern Hemisphere ice sheets.

\section{WIDER IMPLICATIONS}

The thrust of this overview is that information about the evolution of passive continental margins and the processes and forms associated with mid-latitude Northern Hemisphere ice sheets is a useful guide for reconstructing the evolution of the landscape in Antarctica. At present there are insufficient constraints to do more than outline possibilities in a qualitative way. Nonetheless even a preliminary view provides some insights into the debate about the relative importance of fluvial and glacial agents of erosion. Further, there seems ample scope for a focused modeling exercise increasingly founded on quantitative field data.

What is also encouraging about the emerging terrestrial 
record of landscape evolution is that the main stages match the records obtained from deep-sea and inshore cores. At present, given the uncertainties associated with each dating technique, it is not possible to be sufficiently precise to establish cause and effect and thus understand better the links between the ocean, atmosphere, and ice sheet in influencing or responding to environmental change.

One important implication arising from this overview is the realization that fragile features in the landscape can be very old, whether they have been protected beneath ice or subject to a hyperarid climate with minimal erosion. It is possible for striations and moraines to survive for millions of years. Thus, it is possible that features such as trimlines with striations and associated moraines may date from glaciation prior to the mid-Miocene. Pleistocene changes in ice elevation may be indicated only by a sparse scatter of boulders. If so, then reconstructions of former Pleistocene ice thicknesses based solely on trimline and striation evidence can be misleading.

It is worth reflecting on the richness of the record of landscape evolution in Victoria Land. At least in part this must be due to ease of access and proximity to the permanent base of McMurdo Sound. If so, there is the prospect of equally rich archives in other parts of Antarctica. The challenge is to develop and explore these further to improve our understanding of landscape evolution and its contribution to the wider sciences.

\section{ACKNOWLEDGMENTS}

The authors are indebted to the U.K. Natural Environment Research Council for support. Author D.E.S. is grateful for support from the Division of Polar Programs of the U.S. National Science Foundation, the British Antarctic Survey, the Carnegie Trust for the Universities of Scotland and ACE (Antarctic Climate Evolution) Program. We are most grateful to Peter Barrett, David Elliot, Adrian Hall, and Andrew Mackintosh for their thoughtful and helpful comments on the manuscript.

\section{REFERENCES}

Anderson, J. B. 1999. Antarctic Marine Geology. Cambridge: Cambridge University Press.

Baroni, C., V. Noti, S. Ciccacci, G. Righini, and M. C. Salvatore. 2005. Fluvial origin of the valley system in northern Victoria Land (Antarctica) from quantitative geomorphic analysis. Geological Society of America Bulletin 117:212-228.

Barrett, P. J. 2007. Cenozoic climate and sea level history from glacimarine strata off the Victoria Land coast, Cape Roberts Project, Antarctica. In Glacial Processes and Products, eds. M. J. Hambrey, P. Christoffersen, N. F. Glasser, and B. Hubbard. International Association of Sedimentologists Special Publication 39:259-287.

Barrett, P. J., M. J. Hambrey, D. M. Harwood, A. R. Pyne, and P.-N. Webb. 1989. Synthesis. In Antarctic Cenozoic History from CIROS-1 Drillhole, McMurdo Sound, ed. P. J. Barrett. DSIR Bulletin 245:241-251. Wellington: DSIR Publishing.
Beaumont, C., H. Kooi, and S. Willett. 2000. Coupled tectonic-surface process models with applications to rifted margins and collisional orogens. In Geomorphology and Global Tectonics, ed. M. A. Summerfield, pp. 29-55. Chichester: Wiley.

Bentley, M. J., and J. B. Anderson. 1998. Glacial and marine evidence for the ice sheet configuration in the Weddell Sea-Antarctic Peninsula region during the Last Glacial Maximum. Antarctic Science 10:307-323.

Bishop, P., and G. Goldrick, 2000. Geomorphological evolution of the East Australian continental margin. In Geomorphology and Global Tectonics, ed. M. A. Summerfield, pp. 225-254. Chichester: Wiley.

Boulton, G. S. 1996. Theory of glacier erosion, transport and deposition as a consequence of subglacial sediment deformation. Journal of Glaciology $42: 43-62$.

Briner, J. P., G. H. Miller, P. Davis, and R. C. Finkel. 2006. Cosmogenic radionuclides from fjord landscapes support differential erosion by overriding ice sheets GSA Bulletin 118:406-420.

Brook, E. J., E. T. Brown, M. D. Kurz, R. P. Ackert, G. M. Raisbeck, and F. Yiou. 1995. Constraints on age, erosion and uplift of Neogene glacial deposits in the Transantarctic Mountains determined from in situ cosmogenic ${ }^{10} \mathrm{Be}$ and ${ }^{26} \mathrm{Al}$. Geology 23:1057-1152.

Cape Roberts Science Team. 2000. Summary of results. In Studies from Cape Roberts Project: Initial Report on CRP-3, Ross Sea, Antarctica, eds. P. J. Barrett, M. Sarti, and S. Wise. Terra Antartica 7185-203. Siena: Terra Antarctica Publication.

Cooper, A., H. Stagg, and E. Geist. 1991. Seismic stratigraphy and structure of Prydz Bay, Antarctica: Implications from ODP Leg 119 drilling. In Ocean Drilling Program Leg 119 Scientific Results, eds. J. B. Barron and B. Larsen, pp. 5-25. College Station, TX: Ocean Drilling Program.

Cuffey, K. M., H. Conway, A. M. Gades et al. 2000. Entrainment at cold glacier beds. Geology 28:351-354.

De Santis, L., J. B. Anderson, G. Brancolini, and I. Zayatz. 1995. Seismic record of late Oligocene through Miocene glaciation on the central and eastern continental shelf of the Ross Sea. In Geology and Seismic Stratigraphy of the Antarctic Margin, eds. A. K. Cooper, P. F. Barker, and G. Brancolini, Antarctic Research Series 68:235-260. Washington, D.C.: American Geophysical Union.

DeConto, R. M., and D. Pollard. 2003. Rapid Cenozoic glaciation of Antarctica induced by declining atmospheric $\mathrm{CO}_{2}$. Nature 421:245-249.

Denton, G. H., and D. E. Sugden. 2005. Meltwater features that suggest Miocene ice-sheet overriding of the Transantarctic Mountains in Victoria Land, Antarctica. Geografiska Annaler 87A:67-85.

Denton, G. H., J. G. Bockheim, S. C. Wilson, and M. Stuiver. 1989. Late Wisconsin and early Holocene glacial history, inner Ross Embayment, Antarctica. Quaternary Research 31:151-182.

Denton, G. H., M. L. Prentice, and L. H. Burckle. 1991. Cainozoic history of the Antarctic Ice Sheet. In The Geology of Antarctica, ed. R. J. Tingey, pp. 365-433. Oxford: Clarendon Press.

Denton, G. H., J. G. Bockheim, R. H. Rutford, and B. G. Andersen. 1992. Glacial history of the Ellsworth Mountains, West Antarctica. In Geology and Palaeontology of the Ellsworth Mountains, West Antarctica, eds. G. F. Webers, C. Craddock, and J. F. Splettstoesser. Geological Society of America Memoir 170:403-442.

Denton, G. H., D. E. Sugden, D. R. Marchant, B. L. Hall, and T. I. Wilch. 1993. East Antarctic Ice Sheet Sensitivity to Pliocene Climatic Change from a Dry Valleys Perspective. Geografiska Annaler 75A:155-204.

Drewry, D. J. 1982. Ice flow, bedrock and geothermal studies from radioecho sounding inland of McMurdo Sound, Antarctica. In Antarctic Geoscience, ed. C. Craddock, pp. 977-983. Madison: University of Wisconsin Press.

Dunbar, G. B., T. R. Naish, P. J. Barrett, C. R. Fielding, and R. D. Powell. Forthcoming. Constraining the amplitude of late Oligocene bathymetric changes in western Ross Sea during orbitally-induced oscillations in the East Antarctic Ice Sheet. 1. Implications for glacimarine sequence stratigraphic models. Palaeogeography, Palaeoclimatology, Palaeoecology, doi:10.1016/j.palaeo.2007.08.018. 
Ehrmann, W. U., M. Setti, and L. Marinoni. 2005. Clay minerals in Cenozoic sediments off Cape Roberts (McMurdo Sound, Antarctica) reveal the palaeoclimatic history, Palaeogeography, Palaeoclimatology, Palaeoecology 229:187-211.

Evans, I. S. 1969. The geomorphology and morphometry of glacial and nival areas. In Water, Earth and Man, ed. R. J. Chorley, pp. 369-380. London: Methuen.

Evatt, G. W., A. C. Fowler, C. D. Clark, and N. R. J. Hulton. 2006. Subglacial floods beneath ice sheets. Philosophical Transactions of the Royal Society of London 364:1769-1794.

Fitzgerald, P. G. 1992. The Transantarctic Mountains of southern Victoria Land: The application of fission track analysis to a rift shoulder uplift. Tectonics 11:634-662.

Gore, D. B., E. J. Rhodes, P. C. Augustinius, M. R. Leishman, E. A. Colhoun, and J. Rees-Jones. 2001. Bunger Hills, East Antarctica: Ice free at the Last Glacial Maximum. Geology 29:1103-1106.

Hall, B. L., G. H. Denton, D. R. Lux, and J. G. Bockheim. 1993. Late Tertiary Antarctic paleoclimate and ice-sheet dynamics inferred from surficial deposits in Wright Valley. Geografiska Annaler 75A:239-267.

Hambrey, M. J., N. F. Glasser, B. C. McKelvey, D. E. Sugden, and D. Fink. 2007. Cenozoic landscape evolution of an East Antarctic oasis (Radok Lake area, northern Prince Charles Mountains), and its implications for the glacial and climatic history of Antarctica. Quaternary Science Reviews 26:598-626.

Hodgson, D. A., P. E. Noon, W. Vyverman, C. L. Bryant, D. B. Gore, P. Appleby, M. Gilmour, E. Verleyen, A. Sabbe, V. J. Jones, J. C. EllisEvans, and P. B. Wood. 2001. Were the Larsemann Hills ice free through the Last Glacial Maximum? Antarctic Science 13:440-454.

Holbourn, A., W. Kuhn, M. Schulz, and H. Erlenkeuser. 2005. Impacts of orbital forcing and atmospheric carbon dioxide on Miocene ice-sheet expansion. Nature 438:483-487.

Holmlund, P., and J. O. Näslund. 1994. The glacially sculptured landscape in Dronning Maud Land, Antarctica, formed by wet-based mountain glaciation and not by the present ice sheet. Boreas 23:139-148.

Holtedahl, H. 1958. Some remarks on the geomorphology of continental shelves off Norway, Labrador and southeast Alaska. The Journal of Geology 66:461-471.

Holtedahl, H. 1967. Notes on the formation of fjords and fjord valleys. Geografiska Annaler 49A:188-203.

Horton, R. E. 1945. Erosional development of streams and their drainage basins: Hydrophysical approach to quantitative morphology. Geological Society of America Bulletin 56:275-370.

Huber, M., and D. Nof. 2006. The ocean circulation in the Southern Hemisphere and its climatic impacts in the Eocene. Palaeogeography, Palaeoclimatology, Palaeoecology 231:9-28.

Ives, J. D. 1966. Block fields, associated weathering forms on mountain tops and the nunatak hypothesis. Geografiska Annaler 48A:220-223.

Ivy-Ochs, S., C. Schlüchter, P. W. Kubik, B. Dittrich-Hannen, and J. Beer. 1995. Minimum ${ }^{10} \mathrm{Be}$ exposure ages of early Pliocene for the Table Mountain Plateau and the Sirius Group at Mount Fleming, Dry Valleys, Antarctica. Geology 23:1007-1010.

Jamieson, S. S. R., N. R. J. Hulton, D. E. Sugden, A. J. Payne, and J. Taylor. 2005. Cenozoic landscape evolution of the Lambert basin, East Antarctica: The relative role of rivers and ice sheets. Global and Planetary Change 45:35-49.

Jamieson, S. S. R., N. R. J. Hulton, and M. Hagdorn. Forthcoming. Modelling landscape evolution under ice sheets. Geomorphology, doi:10.1016/j.geomorph.2007.02.047.

Kennett, J. P. 1977. Cenozoic evolution of Antarctic glaciation, the circumAntarctic Ocean and their impact on global oceanography. Journal of Geophysical Research 82:3843-3860.

Kerr, A., and W. D. Hermichen. 1999. Glacial modification of the Shackleton Range, Antarctica. Terra Antartica 6:353-360.

Lawver, L. A., and L. M. Gahagan. 2003. Evolution of Cenozoic seaways in the circum-Antarctic region. Palaeogeography, Palaeoclimatology, Palaeoecology 198(1-2):11-37.
Lawver, L. A., L. M. Gahagan, and M. F. Coffin. 1992. The development of seaways around Antarctica. Antarctic Research Series 56:7-30.

Leventer, A., E. Domack, R. Dunbar, J. Pike, C. Stickley, E. Maddison, S. Brachfeld, P. Manley, and C. McLennen. 2006. Marine sediment record from the East Antarctic margin reveals dynamics of ice sheet recession. GSA Today 16(12):4-10.

Lewis, A. R., D. R. Marchant, D. E. Kowalewski, S. L. Baldwin, and L. E. Webb. 2006. The age and origin of the Labyrinth, western Dry valleys, Antarctica: Evidence for extensive middle Miocene subglacial floods and freshwater discharge to the Southern Ocean. Geology 34:513-516.

Lewis, A. R., D. R. Marchant, A. C. Ashworth, S. R. Hemming, and M. L. Machlus. 2007. Major middle Miocene global climate change: Evidence from East Antarctica and the Transantarctic Mountains. Geological Society of America Bulletin 119(11):1449-1461, doi:10.1130/B26134.

Lidmar-Bergstrom, K. 1982. Pre-Quaternary geomorphological evolution in southern Fennoscandia. Sveriges, geologiska undersökning C 785:1-202.

Linton, D. L. 1949. Unglaciated areas in Scandinavia and Great Britain. Irish Geography 2:77-79.

Linton, D. L. 1963. The forms of glacial erosion. Transactions of the Institute of British Geographers 33:1-28.

Løken, O. H., and D. A. Hodgson. 1971. On the submarine geology along the east coast of Baffin Island. Canadian Journal of Earth Sciences 8:185-195.

Lythe, M., D. G. Vaughan, and BEDMAP Consortium. 2001. BEDMAP: A new thickness and subglacial topographic model of Antarctica. Canadian Journal of Earth Sciences 106:11335-11352.

Mackintosh, A., D. White, D. Fink, D. B. Gore, J. Pickard, and P. C. Fanning. 2007. Exposure ages from mountain dipsticks in Mac Robertson Land, East Antarctica, indicate little change in ice-sheet thickness since the Last Glacial Maximum. Geology 35:551-554.

Marchant, D. R., G. H. Denton, D. E. Sugden, and C. C. Swisher III. 1993. Miocene glacial stratigraphy and landscape evolution of the western Asgard Range, Antarctica. Geografiska Annaler 75A:303-330.

Marchant, D. R., A. R. Lewis, W. M. Phillips, E. Moore, R. Souchez, G. H. Denton, and D. E. Sugden. 2002. Formation of patterned ground and sublimation till over Miocene glacier ice, southern Victoria Land, Antarctica. GSA Bulletin 114:718-730.

Margerison, H. R., W. M. Phillips, F. M. Stuart, and D. E. Sugden. 2005. Cosmogenic ${ }^{3} \mathrm{He}$ concentrations in ancient flood deposits from the Coombs Hills, northern Dry Valleys, East Antarctica: Interpreting exposure ages and erosion rates. Earth and Planetary Science Letters 230:163-175.

Mercer, J. H. 1961. The response of fiord glaciers to changes in the firn limit. Journal of Glaciology 3:850-858.

Mercer, J. H. 1978. West Antarctic Ice Sheet and $\mathrm{CO}_{2}$ greenhouse effect: A threat of disaster. Nature 271:321-325.

Naish, T. R. et al. 2001. Orbitally induced oscillations in the East Antarctic ice sheet at the Oligocene/Miocene boundary. Nature 413:719-723.

Näslund, J.-O. 2001. Landscape development in western and central Dronning Maud Land, East Antarctica. Antarctic Science 13:302-311.

Ó Cofaigh, C., R. D. Larter, J. A. Dowdeswell, C.-D. Hillenbrand, C. J. Pudsey, J. Evans, and P. Morris. 2005. Flow of the West Antarctic Ice Sheet on the continental margin of the Bellingshausen Sea at the Last Glacial Maximum. Journal of Geophysical Research 110(B11):103, doi:10.1029/2005JB003619.

O'Brien, P. E., A. K. Cooper, C. Richter et al. 2001. Leg 188 summary: Prydz Bay-Cooperation Sea, Antarctica. Proceedings of the Ocean Drilling Program, Initial Reports 188:1-65. College Station, TX: Ocean Drilling Program.

Payne, A. J. 1999. A thermomechanical model of ice flow in West Antarctica. Climate Dynamics 15:115-125.

Pekar, S. F., and R. M. DeConto. 2006. High-resolution ice-volume estimates for the early Miocene: Evidence for a dynamic ice sheet in Antarctica. Palaeogeography, Palaeoclimatology, Palaeoecology 231:101-109. 
Perkins, D. 1984. Subglacial landscape in Antarctica. Unpublished Ph.D. thesis. University of Aberdeen.

Persano, C., F. M. Stuart, P. Bishop, and D. N. Barfod. 2002. Apatite (U$\mathrm{Th}) / \mathrm{He}$ age constraints on the development of the Great Escarpment on the southeastern Australian passive margin. Earth and Planetary Science Letters 200:79-90.

Prest, V. K. 1970. Quaternary geology of Canada. Economic Geology Report 1:676-764.

Priestley, R. E. 1909. Scientific results of the western journey. In The Heart of the Antarctic, vol. 2, ed. E. H. Shackleton, pp. 315-333. London: Heinemann.

Raine, J. I., and R. A. Askin. 2001. Terrestrial palynology of Cape Roberts drillhole CRP-3, Victoria Land Basin, Antarctica. Terra Antartica 8:389-400.

Reeh, N. 1991. Parameterization of melt rate and surface temperature on the Greenland ice sheet. Polarforschung 59(3):113-128.

Shevenell, A. E., J. P. Kennett, and D. W. Lea. 2004. Middle Miocene Southern Ocean cooling and Antarctic cryosphere expansion. Science 305:1766-1770.

Smith, A. M., T. Murray, K. W. Nicholls, K. Makinson, G. Aoalgeirsdottir, A. E. Behar, and D. G. Vaughan. 2007. Rapid erosion, drumlin formation, and changing hydrology beneath an Antarctic ice stream. Geology 35:127-130.

Sorlien, C. C., B. P. Luyendyk, D. S. Wilson, R. C. Decesari, L. R. Bartel, and J. B. Diebold. 2007. Oligocene development of the West Antarctic Ice Sheet recorded in eastern Ross Sea strata. Geology 35:467-470.

Stern, T. A., A. K. Baxter, and P. J. Barrett. 2005. Isostatic rebound due to glacial erosion within the Transantarctic Mountains. Geology 33:221-224.

Stickley, C. E., H. Brinkhuis, S. A. Schellenberg, A. Sluijs, U. Rohl, M. Fuller, M. Grauert, M. Huber, J. Warnaar, and G. L. Williams. 2004. Timing and nature of the deepening of the Tasmanian Gateway. Paleoceanography PA4027, doi:10.1029/2004PA001022.

Stokes, C. R., and C. D. Clark. 1999. Geomorphological criteria for identifying Pleistocene ice streams. Annals of Glaciology 28:67-74.

Strahler, A. N. 1958. Dimensional analysis applied to fluvially eroded landforms. Bulletin of the Geological Society America 69:279-300.

Stroeven, A. P., D. Fabel, C. Hättestrand, and J. Harbor. 2002. A relict landscape in the centre of Fennoscandian glaciation: Cosmogenic radionuclide evidence of tors preserved through multiple glacial cycles. Geomorphology 44:145-154.

Sugden, D. E. 1977. Reconstruction of the morphology, dynamics and thermal characteristics of the Laurentide ice sheet at its maximum. Arctic and Alpine Research 9:21-47.

Sugden, D. E. 1978. Glacial erosion by the Laurentide ice sheet. Journal of Glaciology 20:367-392.

Sugden, D. E., and G. H. Denton. 2004. Cenozoic landscape evolution of the Convoy Range to Mackay Glacier area, Transantarctic Mountains: Onshore to offshore synthesis. GSA Bulletin 116:840-857.
Sugden, D. E., M. A. Summerfield, G. H. Denton, T. I. Wilch, W. C. McIntosh, D. R. Marchant, and R. H. Rutford. 1999. Landscape development in the Royal Society Range, southern Victoria Land, Antarctica: Stability since the middle Miocene. Geomorphology 28:181-200.

Sugden, D. E., G. Balco, S. G. Cowdery, J. O. Stone, and L. C. Sass III. 2005. Selective glacial erosion and weathering zones in the coastal mountains of Marie Byrd Land, Antarctica. Geomorphology 67:317-334.

Summerfield, M. A. 2000. Geomorphology and global tectonics: Introduction. In Geomorphology and Global Tectonics, ed. M. A. Summerfield, pp. 3-12. Chichester: Wiley.

Summerfield, M. A., D. E. Sugden, G. H. Denton, D. R. Marchant, H. A. P. Cockburn, and F. M. Stuart. 1999. Cosmogenic isotope data support previous evidence of extremely low rates of denudation in the Dry Valleys region, southern Victoria Land. Geological Society of London Special Publication 162:255-267.

Taylor, G. 1922. The Physiography of McMurdo Sound and Granite Harbour Region. British Antarctic (Terra Nova) Expedition, pp. 1910-1913. London: Harrison.

Taylor, J., M. J. Siegert, A. J. Payne, M. J. Hambrey, P. E. O’Brien, A. K. Cooper, and G. Leitchenkov. 2004. Topographic controls on post-Oligocene changes in ice-sheet dynamics, Prydz Bay region, East Antarctica. Geology 32:197-200.

van de Flierdt, T., G. E. Gehrels, S. L. Goldstein, and S. R. Hemming. 2007. Pan-African Age of the Gamburtsev Mountains? In Antarctica: A Keystone in a Changing World-Online Proceedings for the Tenth International Symposium on Antarctic Earth Sciences, eds. Cooper, A. K., C. R. Raymond et al., USGS Open-File Report 2007-1047, Extended Abstract 176, http://pubs.usgs.gov/of/2007/1047/.

van der Wateren, F. M., T. J. Dunai, R. T. Van Balen, W. Klas, A. L. L. M. Verbers, S. Passchier, and U. Herpers. 1999. Contrasting Neogene denudation histories of different structural regions in the Transantarctic Mountains rift flank constrained by cosmogenic isotope measurements. Global and Planetary Change 23:145-172.

Vaughan, D. G., J. L. Bamber, M. Giovinetto, J. Russell, and A. P. R. Cooper. 1999. Reassessment of net surface mass balance in Antarctica. Journal of Climate 12:933-946.

Webb, P.-N. 1994. Paleo-drainage systems of East Antarctica and sediment supply to West Antarctic Rift System basins. Terra Antartica $1: 457-461$

Webb, P.-N., and J. Wrenn. 1982. Upper Cenozoic biostratigraphy and micropaleontology of Taylor Valley, Antarctica. In Antarctic Geoscience, ed. C. Craddock, pp. 117-1122. Madison: University of Wisconsin Press.

Wellner, J. S., A. L. Lowe, S. S. Shipp, and J. B. Anderson. 2001. Distribution of glacial geomorphic features on the Antarctic continental shelf and correlation with substrate: Implications for ice behavior. Journal of Glaciology 47:397-411.

Zachos, J. C., J. Breza, and S. W. Wise. 1992. Early Oligocene ice sheet expansion on Antarctica, sedimentological and isotopic evidence from the Kergulen Plateau. Geology 20:569-573. 